\title{
Swift evolutionary response of microbes to a rise in anthropogenic mercury in the Northern Hemisphere
}

\author{
Matti O. Ruuskanen $\mathbb{( i )}^{1} \cdot$ Stéphane Aris-Brosou (i] ${ }^{1,2} \cdot$ Alexandre J. Poulain $\mathbb{1}^{1}$
}

Received: 12 July 2019 / Accepted: 17 November 2019 / Published online: 12 December 2019

(c) The Author(s), under exclusive licence to International Society for Microbial Ecology 2019. This article is published with open access

\begin{abstract}
Anthropogenic mercury remobilization has considerably increased since the Industrial Revolution in the late 1700s. The Minamata Convention on Mercury is a United Nations treaty (2017) aiming at curbing mercury emissions. Unfortunately, evaluating the effectiveness of such a global treaty is hampered by our inability to determine the lag in aquatic ecosystem responses to a change in atmospheric mercury deposition. Whereas past metal concentrations are obtained from core samples, there are currently no means of tracking historical metal bioavailability or toxicity. Here, we recovered DNA from nine dated sediment cores collected in Canada and Finland, and reconstructed the past demographics of microbes carrying genes coding for the mercuric reductase (MerA)—an enzyme involved in $\mathrm{Hg}$ detoxification—using Bayesian relaxed molecular clocks. We found that the evolutionary dynamics of merA exhibited a dramatic increase in effective population size starting from $1783.8 \pm 3.9 \mathrm{CE}$, which coincides with both the Industrial Revolution, and with independent measurements of atmospheric $\mathrm{Hg}$ concentrations. We show that even low levels of anthropogenic mercury affected the evolutionary trajectory of microbes in the Northern Hemisphere, and that microbial DNA encoding for detoxification determinants stored in environmental archives can be used to track historical pollutant toxicity.
\end{abstract}

\section{Introduction}

Mercury $(\mathrm{Hg})$ is a naturally occurring toxic metal that is globally distributed because of the volatility of its reduced form [1]. Under anoxic conditions, microbes can transform inorganic $\mathrm{Hg}$ into methylmercury, which is bioaccumulated in organisms and biomagnified throughout food webs. $\mathrm{Hg}$ is naturally remobilized from geological sources but anthropogenic emissions have dramatically increased since the Industrial Revolution, which took place around the end of the 18th century [2]. As a consequence of anthropogenic activity, the concentration of $\mathrm{Hg}$ in the atmosphere is

Supplementary information The online version of this article (https:// doi.org/10.1038/s41396-019-0563-0) contains supplementary material, which is available to authorized users.

Alexandre J. Poulain

apoulain@uottawa.ca

1 Department of Biology, University of Ottawa, Ottawa, ON, Canada

2 Department of Mathematics \& Statistics, University of Ottawa, Ottawa, ON, Canada estimated to be almost three times higher than in preindustrial times, and about eight times that of $2000 \mathrm{BCE}$, when $\mathrm{Hg}$ started being used by human civilizations [3]. These estimates are based on biogeochemical models, backed by historical sources [4], archeological evidence [5], and measures of total $\mathrm{Hg}$ in sediment cores [6, 7]. However, historical response of ecosystem components to $\mathrm{Hg}$ has mostly relied on preserved museum specimens [8], because direct tracking of $\mathrm{Hg}$ toxicity and bioavailability in environmental archives, such as ice and sediment cores or permafrost, is currently impossible.

Even though human activities have contributed to increase the amount of $\mathrm{Hg}$ in the environment, we do not know how historical $\mathrm{Hg}$ deposition has affected key microbial players, which often control the amount of $\mathrm{Hg}$ available to food webs [9]. This is a major knowledge gap that potentially hinders policy development, because effective risk reduction strategies depend on a comprehensive understanding of the present and past effects of toxic pollutants on ecosystems [10]. One possibility to track bioavailable $\mathrm{Hg}$ through time is to monitor how microbial systems responded to historical toxic $\mathrm{Hg}$ levels. The bestknown microbial $\mathrm{Hg}$ detoxification mechanism, the meroperon, codes for proteins that efficiently detect, transport, 
Table 1 Geomorphological characterization of the sampling sites

\begin{tabular}{|c|c|c|c|c|c|c|c|c|}
\hline Peak $[\mathrm{THg}]$ & Site & Abbr. & $\begin{array}{l}\text { Sampling } \\
\text { coordinates }\end{array}$ & Lake area & Watershed area & $\begin{array}{l}\text { Catchment area to } \\
\text { lake area ratio }\end{array}$ & $\begin{array}{l}\text { Mean-max. } \\
\text { water depth }\end{array}$ & References \\
\hline $2739 \mathrm{ng} \mathrm{g}^{-1} \mathrm{dw}$ & $\begin{array}{l}\text { Kokemäenjoki/ } \\
\text { Harjavalta }\end{array}$ & HAR & $\begin{array}{l}61.33207^{\circ} \mathrm{N} \\
22.12895^{\circ} \mathrm{E}\end{array}$ & NA (river) & $26100 \mathrm{~km}^{2}$ & n/a (river) & n/a (river) & [78] \\
\hline $1906 \mathrm{ng} \mathrm{g}^{-1} \mathrm{dw}$ & Pocket lake & POK & $\begin{array}{l}62.50897^{\circ} \mathrm{N} \\
114.37377^{\circ} \mathrm{W}\end{array}$ & $0.048 \mathrm{~km}^{2}$ & $0.095 \mathrm{~km}^{2}$ & 1.98 & $2 m-6 m$ & {$[79,80]$} \\
\hline $1057 \mathrm{ng} \mathrm{g}^{-1} \mathrm{dw}$ & Öjanjärvi & OJA & $\begin{array}{l}63.80657^{\circ} \mathrm{N} \\
22.99994^{\circ} \mathrm{E}\end{array}$ & $12 \mathrm{~km}^{2}$ & ${ }^{b} 3970 \mathrm{~km}^{2}$ & 331 & $1.6 \mathrm{~m}-9 \mathrm{~m}$ & [81] \\
\hline $415 \mathrm{ng} \mathrm{g}^{-1} \mathrm{dw}$ & Päiväjärvi & PAI & $\begin{array}{l}63.88923^{\circ} \mathrm{N} \\
23.24727^{\circ} \mathrm{E}\end{array}$ & $0.13 \mathrm{~km}^{2}$ & ${ }^{\mathrm{c}} 0.95 \mathrm{~km}^{2}$ & 7.31 & $\mathrm{n} / \mathrm{a}-1.8 \mathrm{~m}$ & [82] \\
\hline $110 \mathrm{ng} \mathrm{g}^{-1} \mathrm{dw}$ & Aquatuk lake & AQT & $\begin{array}{l}54.3281^{\circ} \mathrm{N} \\
84.5686^{\circ} \mathrm{W}\end{array}$ & $8.28 \mathrm{~km}^{2}$ & ${ }^{c} 231 \mathrm{~km}^{2}$ & 27.9 & $\mathrm{n} / \mathrm{a}-12 \mathrm{~m}$ & [83] \\
\hline $126 \mathrm{ng} \mathrm{g}^{-1} \mathrm{dw}$ & Pulmankijärvi & PUL & $\begin{array}{l}69.97459^{\circ} \mathrm{N} \\
28.00415^{\circ} \mathrm{E}\end{array}$ & $11.2 \mathrm{~km}^{2}$ & $800 \mathrm{~km}^{2}$ & 71.4 & $11 \mathrm{~m}-34 \mathrm{~m}$ & [84-86] \\
\hline $91 \mathrm{ng} \mathrm{g}^{-1} \mathrm{dw}$ & Kevojärvi & KEV & $\begin{array}{l}69.75804^{\circ} \mathrm{N} \\
26.99785^{\circ} \mathrm{E}\end{array}$ & $1.1 \mathrm{~km}^{2}$ & $1470 \mathrm{~km}^{2}$ & 1340 & $11.1 \mathrm{~m}-35 \mathrm{~m}$ & [87] \\
\hline $63 \mathrm{ng} \mathrm{g}^{-1} \mathrm{dw}$ & Lake Hazen & LAH & $\begin{array}{l}81.8245^{\circ} \mathrm{N} \\
70.71604^{\circ} \mathrm{W}\end{array}$ & $540 \mathrm{~km}^{2}$ & $6860 \mathrm{~km}^{2}$ & 12.7 & $95 \mathrm{~m}-267 \mathrm{~m}$ & {$[17,88]$} \\
\hline $50 \mathrm{ng} \mathrm{g}^{-1} \mathrm{dw}$ & $\begin{array}{l}\text { Vuolimus } \\
\text { Cieskuljavri }\end{array}$ & VUO & $\begin{array}{l}69.73197 \mathrm{~N}^{\circ} \\
27.09612^{\circ} \mathrm{E}\end{array}$ & $0.39 \mathrm{~km}^{2}$ & ${ }^{c} 22.5 \mathrm{~km}^{2}$ & 57.7 & $\mathrm{n} / \mathrm{a}-1.9 \mathrm{~m}$ & [89] \\
\hline
\end{tabular}

${ }^{\mathrm{a}}$ Calculated based on lake and watershed area

${ }^{b}$ Watershed area combined with hydrologically connected Luodonjärvi (area $73 \mathrm{~km}^{2}$, mean depth $2.6 \mathrm{~m}$, max depth $11 \mathrm{~m}$ )

${ }^{c}$ Estimated in this study

and reduce the organic and inorganic forms of $\mathrm{Hg}$ to its volatile form, $\mathrm{Hg}^{0}$, which then diffuses out of the cell [9, 11]. It is thought that the mer-operon evolved millions of years ago, in marine hydrothermal environments under strong geogenic $\mathrm{Hg}$ pressure, with subsequent constraints by light, salinity, and redox conditions shaping the evolution of the mercuric reductase MerA (coded by merA; [12]). MerA is (i) specific to $\mathrm{Hg}$ detoxification [13], (ii) omnipresent in the environment [14, 15], and (iii) easily exchanged between coexisting microbial populations via horizontal gene transfers that disconnect this marker from its phylogenetic signal [13]. Therefore, we can expect that merA variants be maintained in a given environment based on the selective advantage these variants provide to the community, rather than segregating based on their taxonomy (vertical inheritance). As such, merA is an ideal candidate to provide molecular insights into historical exposure to $\mathrm{Hg}$. Previous results suggested an association between merA phylogeny and $\mathrm{Hg}$ deposition in a remote region [16], but this work was limited in its spatial scope and by the lack of variation in historical $\mathrm{Hg}$ deposition. To address these shortcomings, we tested if the evolutionary response of merA can be used as a proxy for historical changes in the toxicity, and hence bioavailability, of $\mathrm{Hg}$ in sedimentary archives collected over a much broader spatial scale.

Here, we show that regardless of site or deposition rate, the local effective population sizes of merA increased at an unprecedented rate starting at the beginning of the Industrial Revolution in the Northern Hemisphere. No such response was observed for our control housekeeping gene, rpoB, encoding for the $\beta$-subunit of the bacterial RNA polymerase. Our results show that even small changes in $\mathrm{Hg}$ loadings can have long-lasting effects on the evolutionary dynamics of microbes detoxifying this pollutant, and that the merA gene is a sensitive maker, that can be used to track historical $\mathrm{Hg}$ bioavailability over broad, continental scales.

\section{Material and methods}

\section{Sampling and sample processing}

Intact sediment cores were obtained from eight lakes in Canada and Finland, and a river in Finland, which were selected based on previous data on their $\mathrm{Hg}$ deposition history (Table 1, Fig. 1). Low Hg contamination (max $[\mathrm{THg}]<100$ $\mathrm{ng} \mathrm{g}^{-1} \mathrm{dw}$ ) sites included Lake Hazen (LAH) in NU sampled in May 2015 in the Canadian High Arctic [17], and Lake Kevojärvi (KEV), Lake Vuolimus Cieskuljavri (VUO), and Lake Pulmankijärvi (PUL) subarctic sites sampled in April 2016 in Finland [18]. To sample moderate $\mathrm{Hg}$ contamination (max [THg] from 100 to $1000 \mathrm{ng} \mathrm{g}^{-1} \mathrm{dw}$ ) through long-range transport, we obtained sediment-extracted DNA from a previous study of Aquatuk Lake (AQT), ON, Canada [16], sampled in August 2010; this site also allowed us to validate 
Fig. 1 Locations of sampling sites in Finland (blown up in inset) and northern Canada. By alphabetical order: AQT Lake Aquatuk, HAR River Kokemäenjoki, KEV Lake Kevojärvi, LAH Lake Hazen, OJA Lake Öjanjärvi, PAI Lake Päiväjärvi, POK Pocket Lake, PUL Lake Pulmankijärvi, VUO Lake Vuolimuš Cieskuljávri

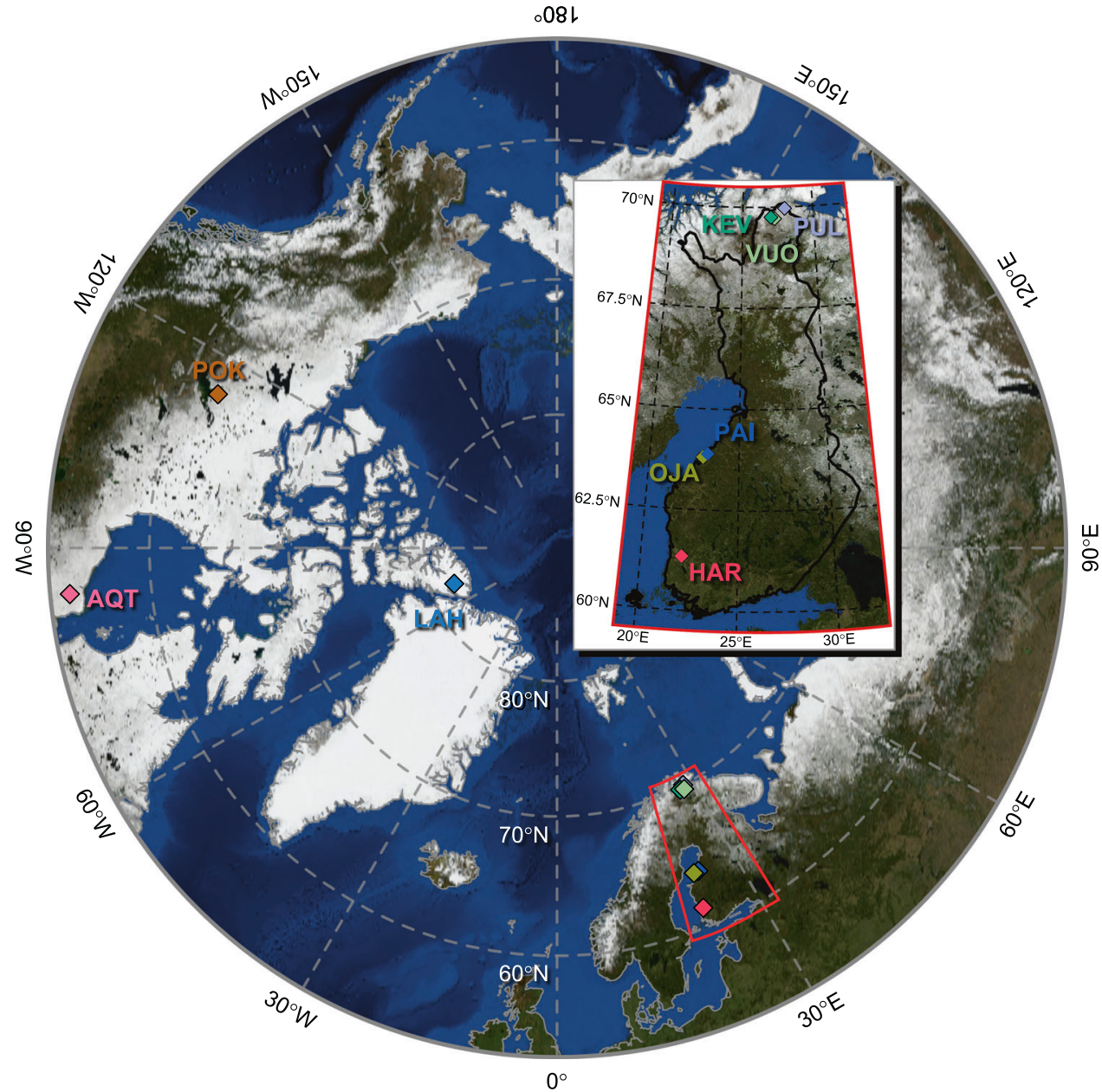

our original findings using different approaches for quantification and sequencing. To represent freshwater sediments with a history of strong anthropogenic $\mathrm{Hg}$ contamination $\left(\max [\mathrm{THg}]>1000 \mathrm{ng} \mathrm{g}^{-1} \mathrm{dw}\right.$ ), we sampled Pocket Lake (POK), YT, Canada in July 2016, as this lake is under the direct influence of toxic metal deposition from the Giant Mine Au roaster [19]. Lake Öjanjärvi (OJA) and Lake Päiväjärvi (PAI) were sampled in May 2016 in Kokkola, Finland, as they are affected by metal deposition from the Ykspihlaja industrial park [20]. River Kokemäenjoki (KOK) was sampled at the dam reservoir in May 2016 in Harjavalta, Finland. The site has a history of strong $\mathrm{Hg}$ pollution from a chloralkali plant upstream and a nearby $\mathrm{Cu} / \mathrm{Ni} / \mathrm{Au} / \mathrm{Ag}$ smelter [21]. Sizes of their watersheds (if not previously available) were calculated based on the digital elevation models and online tools based on ArcGis (ESRI, Redlands, CA, USA; [22, 23]). Sites in Finland were sampled with an HTH sediment corer [24] (Pylonex AB, Umeå, Sweden) except for Kevojärvi, where a wedge type ice finger sampler $(1.5 \mathrm{~m})$ filled with a dry ice/coolant mixture was used to preserve the annual laminae in the sediment. At LAH and POK, a UWITEC gravity corer (Mondsee, Austria) was used. Most of the cores were sectioned at $1 \mathrm{~cm}$ intervals in the field within hours of sampling, and were subsampled from the middle of the sections (avoiding the edges) with sterilized tools to minimize cross-contamination and edge deformations in the cores. The sections from Finnish cores were frozen on dry ice or in a $-80{ }^{\circ} \mathrm{C}$ freezer immediately after sectioning. The POK core was sectioned after sampling with sterilized tools at $0.5 \mathrm{~cm}$ intervals, which were frozen at $-20^{\circ} \mathrm{C}$. The whole core from LAH was frozen at $-18{ }^{\circ} \mathrm{C}$ in the field and sectioned later at $1 \mathrm{~cm}$ intervals while frozen. Both LAH and KEV sections were then subsampled with sterilized tools from the middle of the sections. No chemical preservatives were used for any samples, all sample containers were sterile, and bleachsterilized powder-free nitrile gloves were worn throughout sample handling. After the initial freezing, the samples were shipped frozen, stored at less than $-18{ }^{\circ} \mathrm{C}$, and thawed only directly before DNA extraction.

\section{DNA extraction, chemistry, and dating}

Samples from the cores were homogenized, and DNA extraction was done in duplicate from $0.25 \mathrm{~g}$ (wet weight) 
subsamples of each section. The subsamples were first washed with a buffer (10 mM EDTA, $50 \mathrm{mM}$ Tris- $\mathrm{HCl}, 50$ $\mathrm{mM}$ Na2HPO4.7H2O at $\mathrm{pH} 8.0$ ) to remove PCR inhibitors [16, 25]. Environmental DNA, consisting of nucleic acids from alive, dormant, and dead organisms in the sediment, was extracted with the MOBIO PowerSoil ${ }^{\circledR}$ DNA Isolation Kit (Carlsbad, CA, USA) and the duplicate extracts were combined. Duplicate negative control extractions were made from the wash buffer to assess the kit contamination and combined after extraction.

For chemistry and dating, the core horizons were freeze dried and their water content was measured. THg data for the AQT samples were obtained from a previous study [16], and in other cores it was quantified based on the thermal decomposition, gold amalgamation, and atomic absorption with a MA3000 mercury analyzer (Nippon Instruments Corporation, College Station, TX, USA) at the Laboratory for the Analysis of Natural and Synthetic Environmental Toxins (LANSET, University of Ottawa, ON, Canada; see SI archive for primary measurements). Marine sediment certified reference materials MESS-3 and MESS-4 (National Research Council of Canada), and Buffalo River Sediment NIST-2704 (National Institute of Standards and Technology) were used as calibration controls for [THg] measurements.

Annually laminated (i.e., varved) sediments deposit in Kevojärvi, which enabled dating these sediments in high resolution by varve counting. The dating for the Kevojärvi core in the current study (KEV) was calibrated to a parallel core (KEVO-1) dated earlier by a highly resolved ${ }^{137} \mathrm{Cs}$ profile, where the peaks from the radioactive fallout from Chernobyl accident in 1986 and the 1960's nuclear testing were used to adjust the varve chronology (E. Haltia, University of Turku, personal communication, February 2019). The ${ }^{210} \mathrm{~Pb}$ and ${ }^{137} \mathrm{Cs}$ dating of the other cores for the current study (VUO, PUL, PAI, OJA, KOK, and HAR) was completed with an Ortec High Purity Germanium Gamma Spectrometer (Oak Ridge, TN, USA) at LANSET. Certified reference materials obtained from International Atomic Energy Association (Vienna, Austria) were used for efficiency corrections, and results were analyzed using ScienTissiME (Barry's Bay, ON, Canada). Constant Rate of Supply models were used for all primarily dated cores, and cross-calibrated against the peak in ${ }^{137} \mathrm{Cs}$ (see SI archive). The peak was estimated to occur at 1986 in the Finnish cores (VUO, PUL, PAI, OJA, KOK, and HAR) as deposition from the Chernobyl disaster [26]. Geochronology data from previous studies was used directly for the AQT core [16], and the LAH and POK cores, where the profiles were adjusted for different sampling times. The core from LAH was obtained from the same exact site with the same equipment as a previously ${ }^{210} \mathrm{~Pb}$-dated core [27] and its sedimentation-adjusted dating was used for the new core.
For POK, the ${ }^{210} \mathrm{~Pb}$ dating of a previously analyzed core [19] was used, since we observed no differences in the THg profiles of the cores $(P=0.58$; Fig. S1). For individual horizons in the cores with no direct ${ }^{210} \mathrm{~Pb}$ measurements, dates were estimated either by interpolating between measured horizons or extrapolating the models by fitting a second order polynomial to the modeled dates (all $R^{2}>$ 0.97; Fig. S2). Extrapolations were only performed down to $1750 \mathrm{CE}$, since sediment chronology can be underestimated below supported ${ }^{210} \mathrm{~Pb}$ values [28]. We addressed the potential issue of the mobility of DNA and $\mathrm{Hg}$ within the sediment profiles in a previous study [16].

\section{Gene quantification with droplet digital PCR (ddPCR)}

Copy numbers of merA and $g \ln A$ were quantified from all DNA samples ( $n=126$; Fig. S3) with the Bio-Rad QX200 ddPCR system, and the primary data were processed with the QuantaSoft suite (Bio-Rad, Hercules, CA, USA). Briefly, droplets were generated from PCR reactions according to the manufacturer's guidelines and the reactions were run according to conditions outlined in Table S1, using primers for merA developed in-house and for $g \ln A$ as in [29]. ddPCR enables the quantification of target sequences in samples, similarly to quantitative/real-time PCR, but with simplified workflow, and increased accuracy and precision compared with other quantification methods [30]. The accuracy of the assay was controlled with previously quantified plasmid templates containing the target gene for both merA and $g \ln A$, and elution kit buffer extractions as negative controls. The baselines for positive droplets in each sample were adjusted based on the negative and positive controls. The copy numbers (and 95\% CI) for both genes were then normalized to copies per ng DNA in each sample.

\section{Amplicon sequencing}

The samples were screened for the presence of merA and $r p o B$ with conventional PCR (Table S1). The primers for merA had been designed to target Proteobacteria and Firmicutes [31] and to specifically contain the motif for the terminal cysteine residues in the merA gene. The primers for $r p o B$ were designed for this study with a broad range of specificity (notable exclusions: Cyanobacteria, Gracilibacteria, Microgenomates, and SR1). Despite our best efforts (e.g., fresh reagents and enzymes, changing laboratory space, and equipment), negative controls sometimes were positive for merA (Fig. S4), but never for $r p o B$, which might have been due to the presence of contaminating DNA in the reagents $[32,33]$. We focused on the single-copy housekeeping gene $r р о B$ as a control instead of $g \ln A$ 
because it enabled the design of a PCR amplicon similar in size to merA (and longer than with $g \ln A$, which proved too short for diversity analyses). Furthermore, $r p o B$ is also a marker gene for bacterial phylogeny [34], which is useful for discerning between the variation in overall microbial community structure and variation specific to the merA $\mathrm{Hg}$ resistance gene. Thus, we sequenced 30 samples and a kit negative control for merA, and 30 samples for $r p o B$ (Fig. S3) with Illumina MiSeq (paired-end $250 \mathrm{bp}$ ) at Génome Québec (Montreal, QC, Canada).

\section{Sequencing data processing}

All processing was completed similarly for both merA and $r p o B$ unless otherwise stated. The reads were paired with pear v0.9.10 [35] with $>100$ bp overlap and the stringency set to $P=0.0001$. The primers and barcodes were removed, sequences were truncated to the first ambiguous base call, or where Phred scores fell $<28$ in a 2 bp-window. Sequences shorter than $150 \mathrm{bp}$ were removed with QIIME 1.9.1 [36]. Chimeric sequences were removed with vsearch v2.0.0 [37] utilizing the uchime algorithm [38] against databases of 614 merA or $286 r p o B$ sequences truncated to the amplified region (gene databases are included in the SI archive). To filter nontarget reads, the sequences were translated to amino acids with EMBOSS 6.5.7 [39], searched against custom HMMs (included in the SI archive) constructed from the merA and $r p o B$ databases with HMMER 3.1b2 [40], and sequences not matching the profiles (merA: $E>10^{-25}$; rpoB: $E>10^{-5}$ ) were removed. The nucleotide sequences were then dereplicated and clustered with Swarm 2.1.9 [41], and variant abundances were summarized with custom Perl and $\mathrm{R}$ scripts (see SI archive). The sequences were subset to cluster seeds, aligned with Muscle [42] through TranslatorX [43] to find a common reading frame, and trimmed to the first aligned codon position. The merA sequences that did not encode a Tyr605/Phe605 residue required for activity [13] were removed, and sequences that bridged gaps in the alignments (except for positions after $343 \mathrm{bp}$ for $r p o B$ ) with $<10 \%$ occupancy were removed in both merA and rpoB alignments. The sequences were realigned with MAFFT [44] through TranslatorX, trimmed with trimAl 1.2rev59 [45] using the '-gappyout' option, and sequences still containing gaps were removed.

Out of 2580 quality-controlled merA variants in the samples, $37(1.4 \%)$ were also present in the sequenced negative control (kit extract). These were first removed (Fig. S5), and the remaining read coverage was assessed over estimated calendar dates (Fig. S6). Maximum likelihood trees were constructed from the sequences that passed all quality control steps $(n=2,551)$ with FastTree 2.1.9 [46] using the GTR $+\Gamma$ model of sequence evolution [47]. Long branches, potentially indicating rogue sequences, were then removed with TreeShrink 1.0.0 [48] using a false positive error rate of $\mathrm{FDR}=0.01$, and the trees were rereconstructed with FastTree under the same model as before.

\section{ddPCR data analyses}

For all ddPCR analyses, the data were limited to samples with estimated dating $>1750 \mathrm{CE}$, and the HAR samples were removed because of the mixed core profiles. Briefly, the correlation of gene copy numbers of merA and $g \ln A$ with [THg], dating, and sediment depth (distance from surface of the sediment) were assessed with linear mixedeffects models using 'Imer' from lme4 [49]. The copy numbers were $\log _{10^{-}}$transformed (after assessing the normality of residuals), all variables were scaled and meancentered, and sampling site was used as a random effect (random intercept). Also, identified outliers (see Fig. S3; Pulmankijärvi, points around $1900 \mathrm{CE}$ for $g \ln A$ ) were removed from the final model. The significance of model variables was assessed from the transformed $95 \%$ confidence intervals, and the effect sizes were estimated over their range from model predictions. To compare our ddPCR data against previous studies of merA copy numbers across [THg] [50, 51], we averaged and $\log _{10^{-}}$transformed the normalized copy numbers of merA, and averaged [THg] over the top $5 \mathrm{~cm}$ of sediment samples at each site, and investigated their correlation across the sites with a least square linear regression.

\section{Diversity analyses}

Abundances of merA and rpoB variants within each samples were normalized with cumulative sum scaling with metagenomeSeq [52]. Patterns in beta-diversity (between-sample diversity) of the genes were analyzed with a Double Principle Coordinate Analysis using phylogenetic distances of the variants followed by non-metric multidimensional scaling (NMDS) on the sample distance matrix with phyloseq [53]. Influence of [THg] $\left(\log _{10^{-}}\right.$transformed $\mathrm{ng} \mathrm{g}^{-1}$ $\mathrm{dw}$ ), date (CE), and sampling site on the patterns observed in the ordinations were assessed with the functions "ordisurf" and "factorfit" in vegan [54].

\section{Bayesian demographic reconstructions}

To reconstruct the phylogeny and past population dynamics at the studied lakes, the merA and $r p o B$ variants were first subset per sampling site and variants present in more than one sample per site were removed to eliminate crosscontamination. If there were more than 50 variants in a sample, they were reduced to the most phylogenetically diverse variants by calculating the patristic distances with 
ape [55], followed by Ward's hierarchical clustering [56], and cutting the tree to 50 groups. The timed phylogenies of merA and $r p o B$ were reconstructed for each lake with BEAST v1.8.0 [57] using the GTR $+\Gamma$ model of sequence evolution [47], with a skyline prior on the speciation process, and an uncorrelated lognormal prior on rates [57] (mean $=0.001$, stdev $=1.0$ ); an additional lognormal prior was placed on tree heights (mean $=10$, stdev $=1.0$, offset $=500$ years); chains were started from UPGMA trees. Markov chain Monte Carlo samplers were run in duplicate for up to two billion generations (or until convergence), using a thinning of 20,000 to decorrelate samples; converged duplicate runs were combined after removing burnin periods (between 5 and $35 \%$ of each chain length, according to the mixing of each chain). The maximum $a$ posteriori trees were summarized from the combined collections of trees for each site and gene with TreeAnnotator v1.8.0 [57]. Due to computational limitations, the POK combined trees were thinned to half the sampling frequency of other sites for calculating the summary tree. The association between deposition date of the sample and phylogenies of the gene variants in each lake was tested with BaTS [58] using $10^{3}$ replicates on a subsample of $10^{4}$ trees sampled from the posterior distributions; [16] $P$ values were based on the Association Index [59]. The ancestral demographics estimated with effective population size $\left(N_{e}\right)$ were reconstructed through Bayesian Coalescent Skyline plots using 25 intervals and piecewise-constant spline regressions [60].

\section{Random forest modeling of $N_{e}$ and breakpoint analysis}

To model the overall trends in the demography sizes of both genes, random forests were grown to 5000 trees with ranger [61]. The median of the estimated $N_{e}$ was used as the dependent variable with ${ }^{210} \mathrm{~Pb} /{ }^{137} \mathrm{Cs}$ dates $(\mathrm{CE})$ and sampling sites as predictors (Fig. S7). To assess the stability of model predictions, the data were randomly split ten times while taking care of class imbalance among sites. In the splits, $80 \%$ of the data were used for the training of each model and 20\% for testing. Partial dependence of model predictions on the predictors was analyzed in each of the ten models with edarf [62]. The effect of date was important for the accuracy of model predictions for both genes: a sensitivity analysis showed a decrease in the pseudo- $R^{2}$, when date was omitted from the models, on average from 0.96 to 0.41 for merA and from 0.95 to 0.80 for $r p o B$. The alternative models where $[\mathrm{THg}]$ was added as a predictor had similar performance and results to the main models (Fig. S8), but with a slightly delayed onset of the increase in merA $N_{e}$ and earlier onset for the increase in rpoB $N_{e}$. However, the prediction accuracies of the alternative models, or their results, did not change with the addition of $[\mathrm{THg}]$. Also, its values were imputed (by the overall mean) for missing dates, i.e., before the lowest extent of the [THg] measurements in each core. Thus, we chose the parsimonious model without $[\mathrm{THg}]$. Finally, segmented regression analyses were performed on both the merA and rpoB partial dependence plots of the relationship between date and estimated $N_{e}$ with segmented [63], based on a single breakpoint and a starting value of 1800 .

\section{Results and discussion}

\section{Total mercury concentrations affect merA diversity but not its abundance}

To understand how microbes responded to different levels of anthropogenic $\mathrm{Hg}$ deposition, we collected sediment cores from eight lakes in Canada and Finland, as well as a river in Finland (Fig. 1).

We first tested if the abundance of merA (quantified with ddPCR) correlated with total mercury concentration ([THg]), sediment deposition date, or sampling depth (from sediment surface) in these sediment cores (Fig. S3). We assessed these results against a single-copy housekeeping gene, $g \ln A$, as our first control gene. We found that the copy numbers of merA did not change with sediment depth, nor the estimated deposition date, or even with [THg] (Fig. S9a). However, the number of $g \ln A$ copies, our control gene, decreased with sediment depth (Fig. S9b, c). These results contrast with previous studies reporting an increase in merA copy numbers over long-term $\mathrm{Hg}$ contamination of various soils [50] or with bioavailable $\mathrm{Hg}$ in snowpacks [51] (Fig. S10). However, such studies focused on spatial variation, and did not address the changes over time-or geochemical gradients-at each location.

Given the lack of variation in the abundance of merA along $[\mathrm{THg}]$ gradients, there could instead be changes in its genetic diversity, suggesting the adaptation to increasing $\mathrm{Hg}$ selective pressure. To address this point, we compared the diversity of merA sequences among samples (beta-diversity), both over varying $[\mathrm{THg}]$ and temporal gradients in the sediment cores. In this case, we used an additional control gene, the single-copy housekeeping gene $r p o B$, encoding for the RNA polymerase $\beta$-subunit, to provide more accurate evolutionary information; indeed, $g \ln A$ amplicons proved too short $(<156 \mathrm{bp})$ for this subsequent step of the analysis. These analyses showed that $r p o B$ variants were similar among sites $(P=0.09)$ and countries $(P=0.88)$. On the other hand, merA variants differed significantly among sites $(P=0.01)$, while countries showed similar variational responses $(P=0.30$; Fig. 2$)$. This pattern suggests that merA diversity is affected by $[\mathrm{THg}]$ gradients, contrary to 

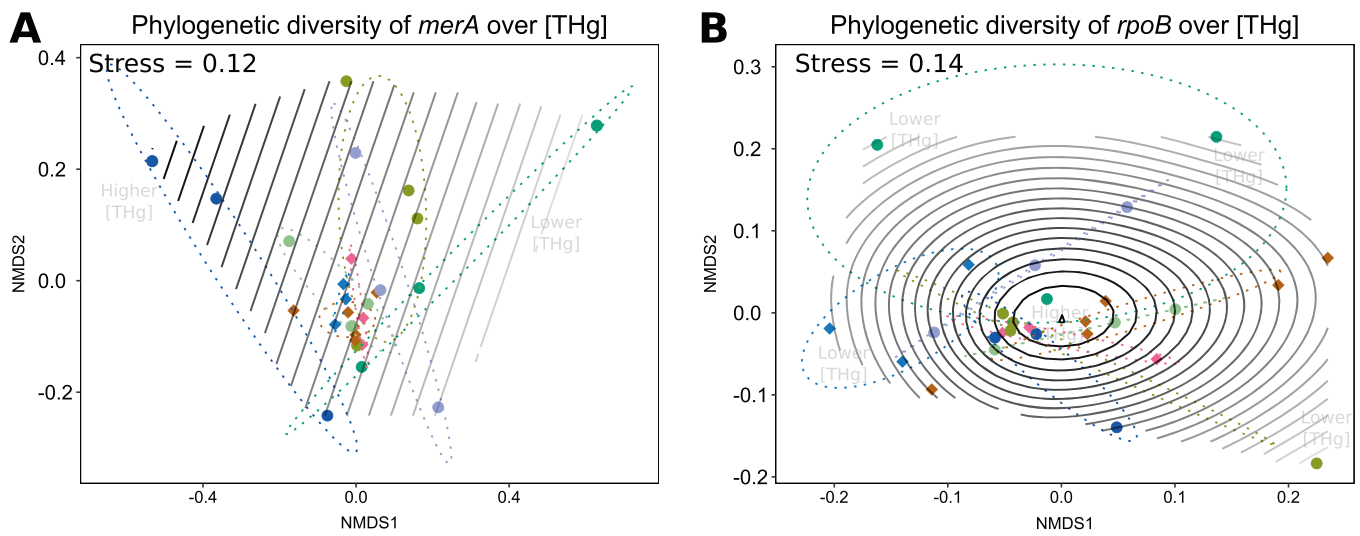

D

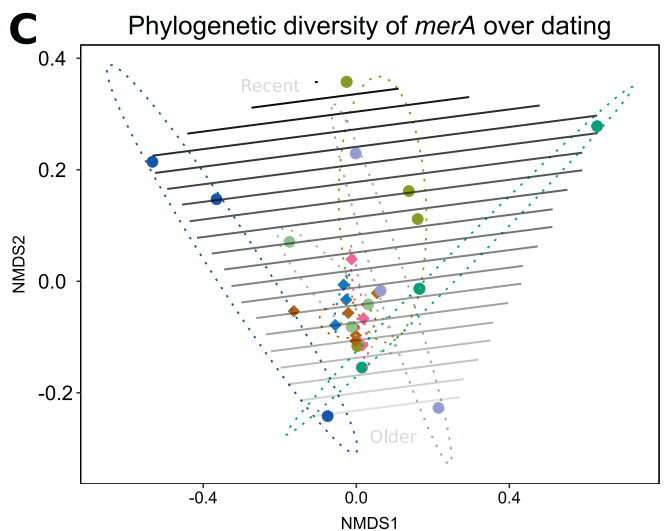

Fig. 2 Beta-diversity of merA and rpoB. Correlations of the NMDS ordination with $[\mathrm{THg}](\mathbf{a}, \mathbf{b})$ and dating $(\mathbf{c}, \mathbf{d})$. Samples from the same site are color-coded and grouped with ellipses. Stress values for the NMDS ordinations are indicated in $\mathbf{a}$ and $\mathbf{b}$, and are identical for $\mathbf{c}$ and d, respectively. All effects tested by the general additive models for

rpoB. To confirm this observation, we fitted General Additive Models (GAM) of [THg] and dating on the ordinations of merA and $r p o B$ diversity. All these fits were significant $\left(P<10^{-17}\right)$, with merA's beta-diversity correlating linearly with both $[\mathrm{THg}]$ and temporal (dating) gradients. The diversity of $r p o B$ failed to show any significant linear response to any of these gradients, only exhibiting phylogenetic similarity at the sediment surfaces (Fig. 2).

These contrasted results suggest that the two genes, merA and $r p o B$, have responded differently to an increased $\mathrm{Hg}$ deposition over time. As merA codes for a protein (MerA) whose sole known function is to detoxify $\mathrm{Hg}$, it can be posited that merA's evolutionary trajectory has been affected by historical changes in $\mathrm{Hg}$ deposition.

\section{Swift evolutionary response of merA from the onset of the Industrial Revolution}

To test this hypothesis, we reconstructed both the phylogeny and past demographics of microbes carrying merA genes with Bayesian relaxed molecular clocks [64]. First, the trees constructed for merA showed a significant association $(P<0.01)$ with the sediment horizon (i.e., depth/ date, as a categorical variable) in all lakes except for Vuolimus Cieskuljavri, which may be due to its low $[\mathrm{THg}]$ $\left(\max [\mathrm{THg}]=50.4 \mathrm{ng} \mathrm{g}^{-1}\right.$ dw; Fig. 3).

This clustering of phylogenetic clades by dates not only argues against stratigraphic leakage of both $m e r A$ and $\mathrm{Hg}$, but also suggests a rapid evolutionary turnover, where merA gene variants are replaced from one horizon to the next. Critically, such a high turnover was however not observed for our control gene, $r p o B$, where this association between sediment horizon and phylogeny was significant in only three out of eight (38\%) sites.

Even if the significance of this gene-specific association of clades with dates cannot be rejected (Binomial test, $P=$ $0.73), r р о в$ is considered to be a reliable phylogenetic marker gene in bacteria [34] and such associations might reflect the structuring of the microbial communities in sediments in response to in-situ physical and geochemical gradients developing over time in surface sediments (e.g., [65]). Because beta-diversity patterns inferred for $r p o B$ differed from that of merA's, the phylogenetic signal recorded in each gene seems to be driven by different 


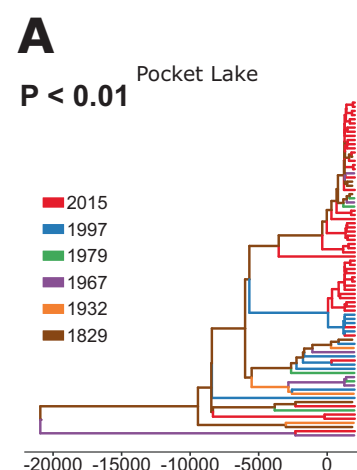

$-20000-15000-10000-5000$

$P<0.01$
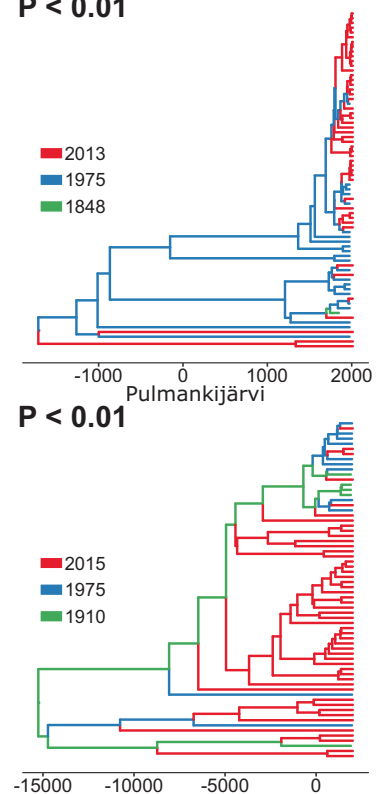

$-15000-10000-5000$

$\mathbf{P}<0.01$

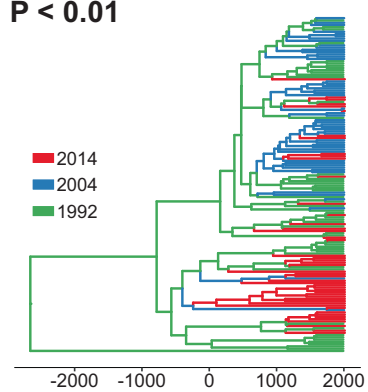

merA

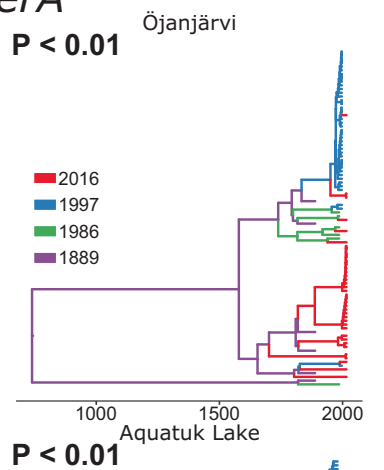

$P<0.01$

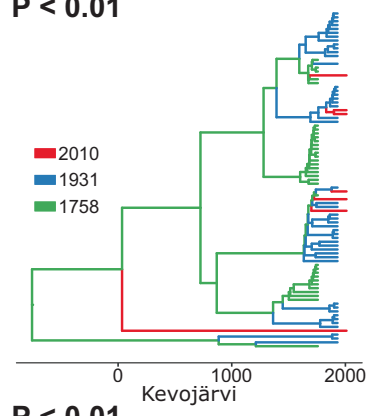

$P<0.01$

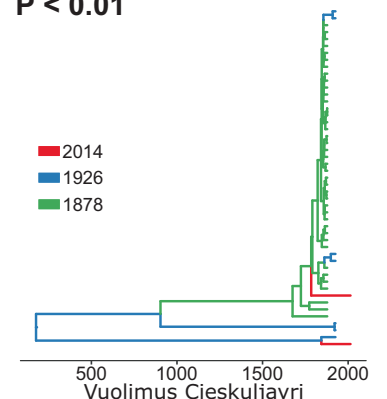

$P>0.01$

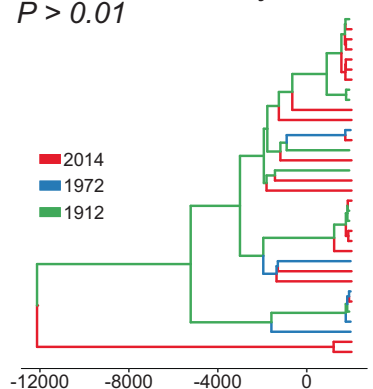

B
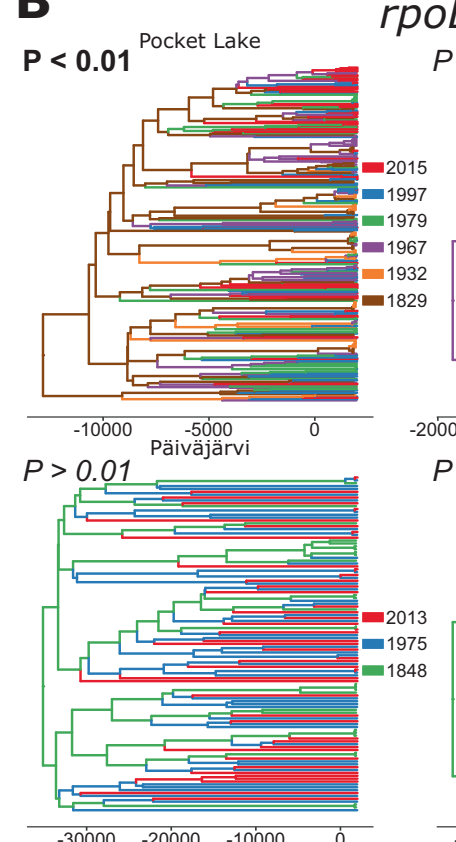

$\begin{array}{ll}-30000 & -20000-10000 \\ \text { Pulmankijärvi } & 0\end{array}$

$P<0.01$

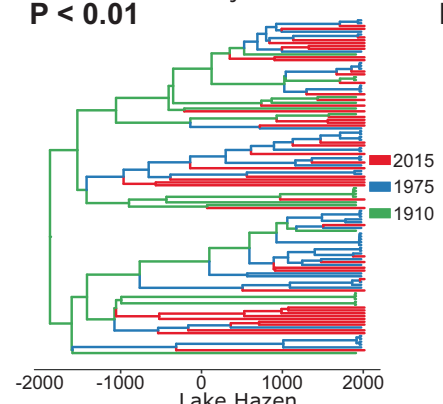

$\begin{array}{cccc}-2000 & -1000 & 0 & 1000 \\ \text { Lake Hazen } & 2000\end{array}$

$P<0.01$

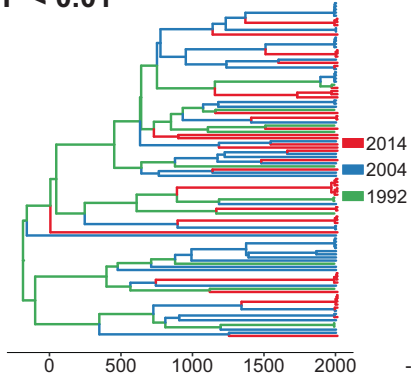

$P>0.01$ Öjanjärvi

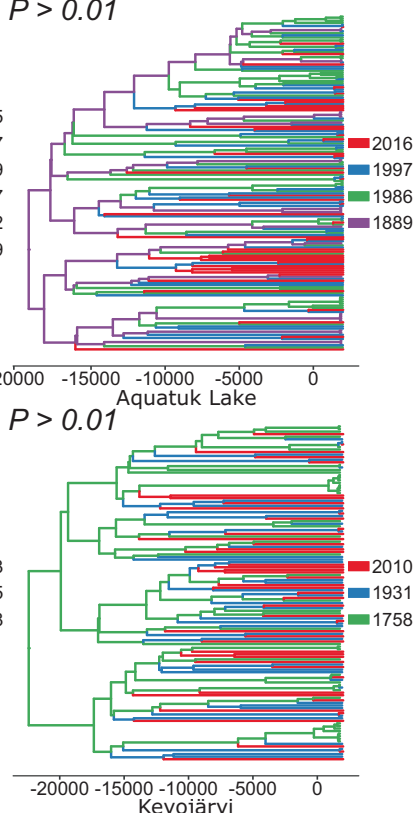

$\mathbf{P}=\mathbf{0 . 0 1}$

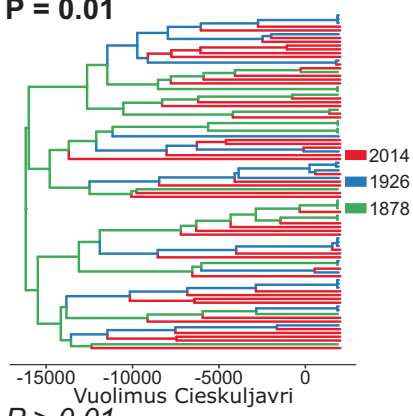

$P>0.01$

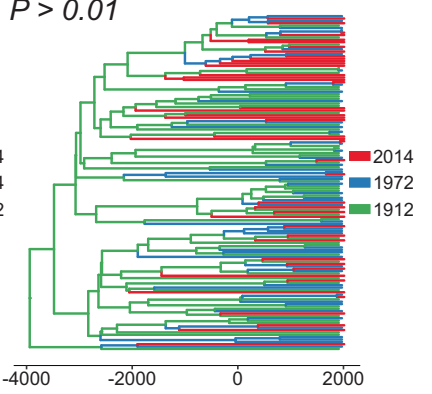

Fig. 3 Maximum a posteriori trees from the relaxed molecular clock analyses. Trees are shown for merA (a) and $\operatorname{rpoB}$ (b) at each site. Sampling horizons were color-coded as shown next to each tree and

processes at the microbial community level. This lack of a clear signal prompted us to go beyond a mere phylogenetic assessment, and to further evaluate how $\mathrm{Hg}$ delivery affected the evolutionary dynamics of the two genes.

Our reconstructions of the merA demographics based on Bayesian skylines showed sigmoidal increases in the scaled effective population sizes $\left(N_{e}\right)$ of this gene over time at most are identical across trees for the topmost three horizons. The $x$-axes are in unit of CE years

sites, matching the trends in [THg] (Fig. S11a). In contrast to $m e r A$, the $N_{e}$ of $r p o B$ varied widely (Fig. S11b) and did not seem to coincide with any trends in $[\mathrm{THg}]$ at any of the sites, which is consistent with the results of our GAM analyses (Fig. 2). Finally, to average over these site-specific responses, we fitted random forest models to the reconstructed demographics for each gene, over all the sampled 
Fig. 4 Partial dependence plots of predicted effective population size as a function of calendar date for merA (a) and rpoB (b). Results are shown from fitting ten randomized models for each gene. The pseudo- $R^{2}$ scores quantify average prediction accuracy of the models, which also included the sampling site as a variable. The black lines show the segmented linear model fits and the blue lines indicate their breakpoints (dotdash lines) surrounded by their 99\% CI (dotted lines). Dashed orange lines show the smoothed atmospheric $\mathrm{Hg}$ concentrations in subarctic Canada and were redrawn using data from [73] (color figure online)

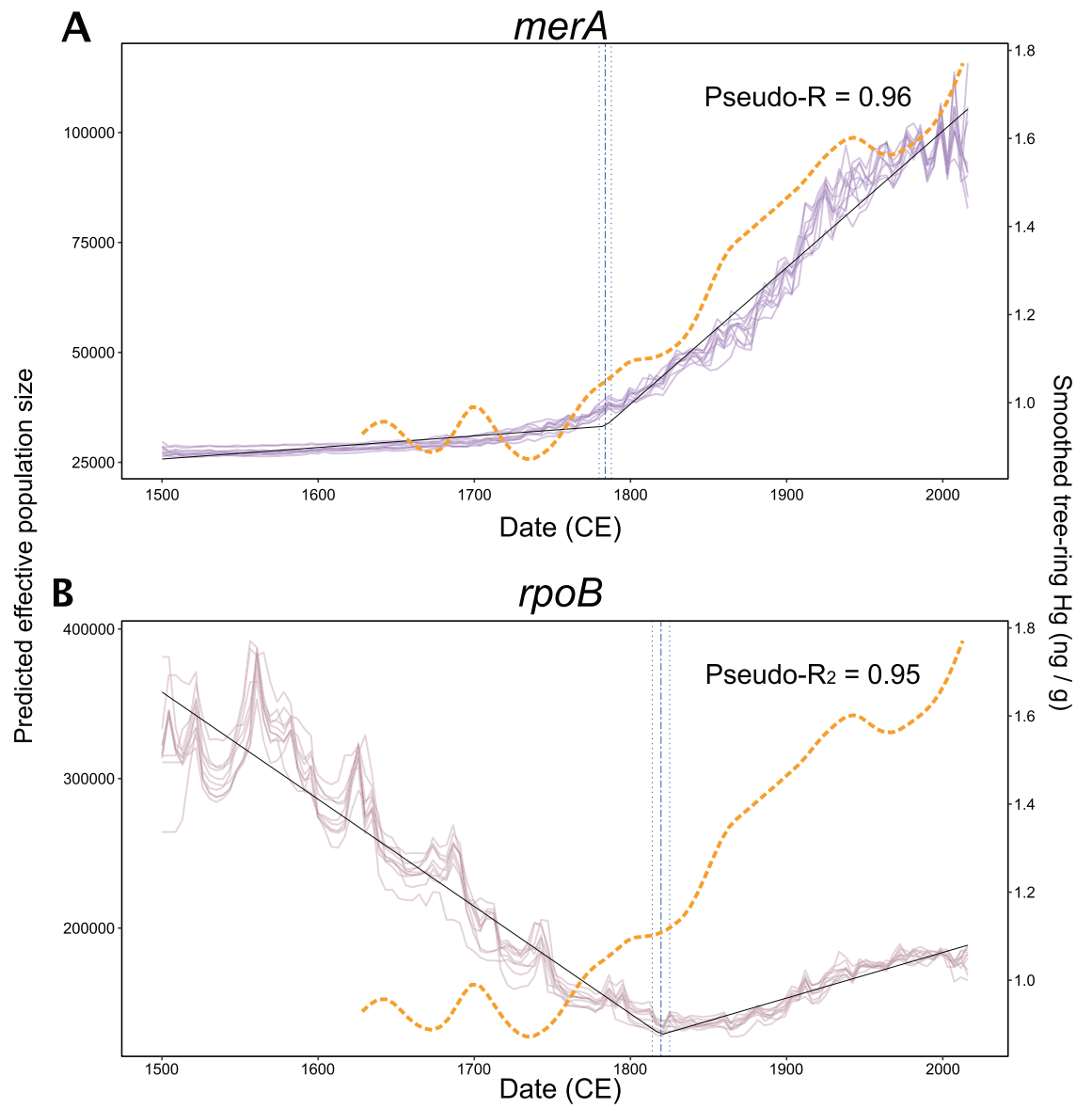

sites (Fig. 4). We found that merA's demographics initially exhibited a slow increase of $N_{e}$, followed by a sharp increase through time (pseudo- $R^{2}=0.96$; Fig. 4a). Again, these trends were not observed for $r p o B$ (pseudo- $R^{2}=0.95$; Fig. 4b). To determine the dates at which these demographic dynamics changes occurred, we fitted segmented regressions of the partial dependence of $N_{e} v s$. date.

For merA, we estimated that the reconstructed paleodemographics changed around 1783.8 \pm 3.9 CE (99\% CI; adjusted $R^{2}=0.98$, Fig. $4 \mathrm{a}$ ), date after which the rate of increase rose by an order of magnitude. The latest global increases in $\mathrm{Hg}$ deposition originated from the increased wood burning in North America [66] at the end of the 18th century, and coal combustion fueling the Industrial Revolution in Europe, which began around 1760 [67, 68]. For comparison, we overlaid atmospheric $\mathrm{Hg}^{0}$ concentrations from high-resolution tree-ring data in subarctic Canada [69] on our reconstructed demographics of merA (Fig. 4a). The temporal coherence of merA $N_{e}$, derived solely using sediment DNA, and that of atmospheric $\mathrm{Hg}^{0}$ levels, is striking, and independently supports an increase in $\mathrm{Hg}$ selective pressure. Our results show that across our sites, located up to $5500 \mathrm{~km}$ apart in the Northern Hemisphere, historical anthropogenic $\mathrm{Hg}$ emissions affected the evolutionary dynamics of merA-allowing us to track variations in $\mathrm{Hg}$ toxicity, and hence bioavailability, through time. The magnitude of the evolutionary response of merA to an increased $\mathrm{Hg}$ deposition was likely related to changes in bioavailable $\mathrm{Hg}$ causing a selective pressure on merA, rather than solely to changes in [THg]. Indeed, the total concentration of a metal is rarely a good predictor of its toxicity, and this is true for $\mathrm{Hg}$ [13]. Rather, metal speciation, i.e., the complexes that a metal forms with inorganic and organic ligands in a solution and at interfaces, affects how metals interact with living cells, causing toxicity [70]. Only total $\mathrm{Hg}$ concentrations, and not $\mathrm{Hg}$ bioavailability or toxicity, can be directly determined from environmental archives. As environmental conditions change over time, we can expect that microbes present in the water column or in surface sediments be exposed to different levels of $\mathrm{Hg}$ exhibiting varying bioavailability and toxicity, and record these variations in selective pressures in their genomes. Furthermore, $\mathrm{Hg}$ bioavailability might differ among sites due to differences in local geochemistry affecting $\mathrm{Hg}$ speciation (e.g., [dissolved organic matter]; [71, 72]). Such local difference can be observed for POK and Öjanjärvi (Fig. S11a). 
For the control gene $r p o B$, the reconstructed paleodemographics were highly variable compared with merA, decreasing since the $1500 \mathrm{~s}$, and started to increase around $1819.6 \pm 5.6 \mathrm{CE}\left(99 \% \mathrm{CI}\right.$; adjusted $R^{2}=0.93$; Fig. $4 \mathrm{~b}$ ). Unlike merA, for which $\mathrm{Hg}$ concentration and speciation are drivers that can directly explain its demographics, the driving forces behind $r p o B N_{e}$ remain unclear, and are likely plural and complex. These rpoB demographics reconstructions need to be interpreted carefully. Indeed, as previously mentioned, and contrary to merA, our GAM analyses determined that there was no significant linear association between $r p o B$ diversity and depth or time, and the Bayesian relaxed molecular clocks only supported the clustering of $r p o B$ phylogenetic clades by dates in three of the studied lakes. Contrary to merA, it is more likely that the changes in $N_{e}$ of $r p o B$ were caused by a restructuring of the sediment microbial communities driven by in-situ geochemical gradients, as implied by our beta-diversity results. Whether or not $N_{e}$ of $r р о B$ also responded to global drivers of change (e.g., temperature, $\mathrm{pCO}_{2}$ ), in addition to local drivers, remains to be tested. Here, the critical point is that, irrespective of what the drivers of the evolutionary dynamics of rрoB are, changes in rpoB's $N_{e}$ are not driven by historical changes in $\mathrm{Hg}$ loadings, and strongly contrast with the paleodynamics reconstructed for merA.

The evolutionary effects of an increase in $\mathrm{Hg}$ loadings on $m e r A$ were sensitive, rapid, and long lasting. These observations warrant continued monitoring of the sites sampled in this study as stricter emission regulations are being implemented. Additional sampling sites should cover the Southern Hemisphere and sites that have experienced sustained and extreme historical $\mathrm{Hg}$ levels. However, sites experiencing high $\mathrm{Hg}$ pollution, such as Kokemäenjoki/ Harjavalta, need to be chosen carefully, as they are often heavily mined or subjected to remediation strategies involving physical alteration of soil or sediments; such physical alterations render them unsuitable for dating and subsequent demographic reconstructions. Finally, to support our field observations, laboratory experimental evolution approaches will be useful to hone the evolutionary models and test for the reproducibility of their trajectories [73].

With implementation of the Minamata convention underway [74], gaining insights into historical responses of biota to anthropogenic $\mathrm{Hg}$ is critical. Indeed, a recent study showed divergence between $\mathrm{Hg}$ levels in aquatic wildlife and atmospheric values, especially in the last two decades [75], that might be caused by climate change. The overriding and opposite effect that climate change may have on a reduction of $\mathrm{Hg}$ emissions requires that governments and environmental agencies worldwide be equipped with the means to accurately assess the efficiency of the reduction of $\mathrm{Hg}$ emissions on ecosystem health. In addition to the ongoing efforts to track the loss of eukaryotic biodiversity and habitat [76], equal if not greater scrutiny should be paid to the concurrent changes in the distribution, abundance and activities of microorganisms affected by the consequences of anthropogenic activities. In this study, we highlighted how the evolutionary dynamics of a discrete microbial gene have responded to human activities. We posit that our findings can be applied to any globally distributed contaminants for which microbes have evolved specific detoxification determinants. In the near future, it is reasonable to think that improved sequencing throughput and advances in computational techniques, which now allow for the recovery of thousands of genomes from environmental metagenomes [77], will help determine the paleodemographics of multiple genetic determinants simultaneously. This would provide much needed genome-level information on the historical response of microbes to ongoing anthropogenic environmental changes.

\section{Data availability}

All code and primary data in this study are available through GitHub (https://github.com/Begia/merA-evolution/). The raw sequence data and the quality-controlled $m e r A$ and $r p o B$ variant sequences have been submitted in NCBI repositories. These data are stored and can be accessed under the bioproject 'PRJNA539962' (http://www.ncbi.nlm.nih.gov/ bioproject/PRJNA539962).

Acknowledgements We would like to thank Marko Virta, his research group, and Timo Saarinen for logistic support in Finland, Sami Jokinen, Jukka Mattila (Water Protection Association of the River Kokemäenjoki), Eeva-Kaarina Aaltonen (Pohjanmaan Vesi ja Ympäristö ry), and Juhani Hannila (City of Kokkola) for their help during fieldwork, Sofia Perin, Emmanuel Yumvihoze and Julian Evans for their assistance with chemical analyses, and the analysis of ddPCR data, Linda Kimpe for help with sediment dating and the Ontario's Centre for Advanced Computing and CSC - IT Center for Science Ltd for providing us with access to their servers. Sampling at Lake Hazen was supported by a NSERC Northern Supplement and ArcticNet funding to AJP with the support of V. St Louis and K. St Pierre. We thank the anonymous reviewers for providing constructive comments that improved this manuscript. This work was funded by the Natural Sciences and Engineering Research Council of Canada (AJP \& SA-B), the Canadian Foundation for Innovation (AJP, SA-B), an Invitational Fellowship from the Japanese Society for the Promotion of Science (SA-B), and the Finnish Academy of Science and Letters/the Vilho, Yrjö, and Kalle Väisälä Fund (MOR).

Author contributions MOR, AJP, and SA-B designed the experiments. MOR performed the sampling, laboratory work, data analysis, and drafted the manuscript. AJP and SA-B supervised the project. All authors contributed to the writing and accepted the final version of the manuscript.

\section{Compliance with ethical standards}

Conflict of interest The authors declare that they have no conflict of interest. 
Publisher's note Springer Nature remains neutral with regard to jurisdictional claims in published maps and institutional affiliations.

Open Access This article is licensed under a Creative Commons Attribution 4.0 International License, which permits use, sharing, adaptation, distribution and reproduction in any medium or format, as long as you give appropriate credit to the original author(s) and the source, provide a link to the Creative Commons license, and indicate if changes were made. The images or other third party material in this article are included in the article's Creative Commons license, unless indicated otherwise in a credit line to the material. If material is not included in the article's Creative Commons license and your intended use is not permitted by statutory regulation or exceeds the permitted use, you will need to obtain permission directly from the copyright holder. To view a copy of this license, visit http://creativecommons. org/licenses/by/4.0/.

\section{References}

1. Driscoll CT, Mason RP, Chan HM, Jacob DJ, Pirrone N. Mercury as a global pollutant: sources, pathways, and effects. Environ Sci Technol. 2013;47:4967-83.

2. Selin NE. Global biogeochemical cycling of mercury: a review. Annu Rev Environ Resour. 2009;34:43-63.

3. Amos HM, Jacob DJ, Streets DG, Sunderland EM. Legacy impacts of all-time anthropogenic emissions on the global mercury cycle. Glob Biogeochem Cycles. 2013;27:410-21.

4. Nriagu JO. Mercury pollution from the past mining of gold and silver in the Americas. Sci Total Environ. 1994;149:167-81.

5. Brooks WE. Industrial use of mercury in the ancient world. In: Bank M, Bank M (eds). pp 19-24. University of California Press, Berkeley, CA, USA. Mercury in the Environment. 2012.

6. Cooke CA, Balcom PH, Biester H, Wolfe AP. Over three millennia of mercury pollution in the Peruvian Andes. Proc Natl Acad Sci. 2009;106:8830-4.

7. Elbaz-Poulichet F, Dezileau L, Freydier R, Cossa D, Sabatier P. A 3500-year record of $\mathrm{Hg}$ and $\mathrm{Pb}$ contamination in a mediterranean sedimentary archive (the Pierre Blanche Lagoon, France). Environ Sci Technol. 2011;45:8642-7.

8. Vo A-TE, Bank MS, Shine JP, Edwards SV. Temporal increase in organic mercury in an endangered pelagic seabird assessed by century-old museum specimens. Proc Natl Acad Sci USA. 2011;108:7466-71.

9. Barkay T, Wagner-Dobler I. Microbial transformations of mercury: potentials, challenges, and achievements in controlling mercury toxicity in the environment. Adv Appl Microbiol. 2005; $57: 1-52$.

10. Hsu-Kim H, S. Eckley C,E, Selin N. Modern science of a legacy problem: mercury biogeochemical research after the Minamata Convention. Environ Sci Process Impacts. 2018;20:582-3.

11. Mathema VB, Thakuri BC, Sillanpää M. Bacterial mer operonmediated detoxification of mercurial compounds: a short review. Arch Microbiol. 2011;193:837-44.

12. Boyd ES, Barkay T. The mercury resistance operon: from an origin in a geothermal environment to an efficient detoxification machine. Front Microbiol. 2012;3:349.

13. Barkay T, Miller SM, Summers AO. Bacterial mercury resistance from atoms to ecosystems. FEMS Microbiol Rev. 2003;27:355-84.

14. Osborn AM, Bruce KD, Strike P, Ritchie DA. Distribution, diversity and evolution of the bacterial mercury resistance (mer) operon. FEMS Microbiol Rev. 1997;19:239-62

15. Barkay T, Kritee K, Boyd E, Geesey G. A thermophilic bacterial origin and subsequent constraints by redox, light and salinity on the evolution of the microbial mercuric reductase. Environ Microbiol. 2010;12:2904-17.
16. Poulain AJ, Aris-Brosou S, Blais JM, Brazeau M, Keller W, Paterson AM. Microbial DNA records historical delivery of anthropogenic mercury. ISME J 2015;9:2541-50.

17. Köck G, Muir D, Yang F, Wang X, Talbot C, Gantner N, et al. Bathymetry and sediment geochemistry of Lake Hazen (Quttinirpaaq National Park, Ellesmere Island, Nunavut). Arctic. 2012; 65:56-66.

18. Rekolainen S, Verta M, Järvinen O. Mercury in snow cover and rainfall in Finland 1983-1984. Vesihallitus. National Board of Waters, Helsinki, Finland; 1986.

19. Thienpont JR, Korosi JB, Hargan KE, Williams T, Eickmeyer DC, Kimpe LE, et al. Multi-trophic level response to extreme metal contamination from gold mining in a subarctic lake. Proc Biol Sci. 2016;283:1836.

20. Vuori K-M, Swanljung, T, Aaltonen E-A, Kalliolinna M, Jokela S. Kokkolan edustan merialueen sedimenttien toksisuus ja ekologinen riskinarviointi. Suomen ympäristö 1/2009, Suomen ympäristökeskus: Edita Publishing, Helsinki, Finland; 2009. http://hdl.handle.net/10138/38007?locale-attribute=en.

21. Schultz T, Korhonen P, Virtanen M. A mercury model used for assessment of dredging impacts. Water, Air, Soil Pollut. 1995; 80:1171-80.

22. Ontario Ministry of Natural Resources and Forestry. Provincial Mapping O. Ontario Flow Assessment Tool. Ontario Ministry of Natural Resources and Forestry, Peterborough, ON, Canada; 2013. Peterborough, Ontario, Canada. https://www.javacoeapp. lrc.gov.on.ca/geonetwork/srv/en/main.home?uuid=b5802601471c-443c-8b67-83260d09c3e2. Accessed: 15 Nov 2018.

23. Finnish Forest Center, Suomen Metsäkeskus. Valuma-alueen määritystyökalu. 2017. https://metsakeskus.maps.arcgis.com/a pps/webappviewer/index.html?id=4ab572bdb631439d82f8aa 8e0284f663. Accessed: 15 Nov 2018.

24. Renberg I, Hansson H. The HTH sediment corer. J Paleolimnol. 2008:40:655-9.

25. Zhou J, Bruns MA, Tiedje JM. DNA recovery from soils of diverse composition. Appl Environ Microbiol. 1996;62:316-22.

26. Kansanen PH, Jaakkola T, Kulmala S, Suutarinen R. Sedimentation and distribution of gamma-emitting radionuclides in bottom sediments of southern Lake Päijänne, Finland, after the Chernobyl accident. Hydrobiologia. 1991;222:121-40.

27. Lehnherr I, Louis VLS, Sharp M, Gardner AS, Smol JP, Schiff SL, et al. The world's largest high Arctic lake responds rapidly to climate warming. Nat Commun. 2018;9:1290.

28. Cooke CA, Hobbs WO, Michelutti N, Wolfe AP. Reliance on $210 \mathrm{~Pb}$ chronology can compromise the inference of preindustrial $\mathrm{Hg}$ flux to lake sediments. Environ Sci Technol. 2010;44: 1998-2003.

29. Hurt RA, Qiu X, Wu L, Roh Y, Palumbo AV, Tiedje JM, et al. Simultaneous recovery of RNA and DNA from soils and sediments. Appl Environ Microbiol. 2001;67:4495-503.

30. Pinheiro LB, Coleman VA, Hindson CM, Herrmann J, Hindson BJ, Bhat S, et al. Evaluation of a droplet digital polymerase chain reaction format for DNA copy number quantification. Anal Chem. 2012;84:1003-11.

31. Wang Y, Boyd E, Crane S, Lu-Irving P, Krabbenhoft D, King S, et al. Environmental conditions constrain the distribution and diversity of archaeal merA in Yellowstone National Park, Wyoming, USA. Microb Ecol. 2011;62:739-52.

32. Glassing A, Dowd SE, Galandiuk S, Davis B, Chiodini RJ. Inherent bacterial DNA contamination of extraction and sequencing reagents may affect interpretation of microbiota in low bacterial biomass samples. Gut Pathog. 2016;8:24.

33. Salter SJ, Cox MJ, Turek EM, Calus ST, Cookson WO, Moffatt $\mathrm{MF}$, et al. Reagent and laboratory contamination can critically impact sequence-based microbiome analyses. BMC Biol. 2014;12:87. 
34. Case RJ, Boucher Y, Dahllöf I, Holmström C, Doolittle WF, Kjelleberg S. Use of $16 \mathrm{~S}$ rRNA and rpoB genes as molecular markers for microbial ecology studies. Appl Environ Microbiol. 2007;73:278-88.

35. Zhang J, Kobert K, Flouri T, Stamatakis A. PEAR: a fast and accurate Illumina paired-End reAd mergeR. Bioinformatics. 2014;30:614-20.

36. Caporaso JG, Kuczynski J, Stombaugh J, Bittinger K, Bushman FD, Costello EK, et al. QIIME allows analysis of high-throughput community sequencing data. Nat Methods. 2010;7:335-6.

37. Rognes T, Flouri T, Nichols B, Quince C, Mahé F. VSEARCH: a versatile open source tool for metagenomics. PeerJ 2016;4:e2584.

38. Edgar RC, Haas BJ, Clemente JC, Quince C, Knight R. UCHIME improves sensitivity and speed of chimera detection. Bioinformatics. 2011;27:2194-200.

39. Rice P, Longden I, Bleasby A. EMBOSS: the European Molecular Biology Open Software Suite. Trends Genet. 2000;16:276-7.

40. Finn RD, Clements J, Arndt W, Miller BL, Wheeler TJ, Schreiber F, et al. HMMER web server: 2015 update. Nucleic Acids Res. 2015;43:W30-8.

41. Mahé F, Rognes T, Quince C, de Vargas C, Dunthorn M. Swarm v2: highly-scalable and high-resolution amplicon clustering. PeerJ. 2015;3:e1420.

42. Edgar RC. MUSCLE: multiple sequence alignment with high accuracy and high throughput. Nucleic Acids Res. 2004;32: $1792-7$.

43. Abascal F, Zardoya R, Telford MJ. TranslatorX: multiple alignment of nucleotide sequences guided by amino acid translations. Nucleic Acids Res. 2010;38:W7-13.

44. Katoh K, Standley DM. MAFFT Multiple Sequence Alignment Software Version 7: improvements in performance and usability. Mol Biol Evol. 2013;30:772-80.

45. Capella-Gutiérrez S, Silla-Martínez JM, Gabaldón T. trimAl: a tool for automated alignment trimming in large-scale phylogenetic analyses. Bioinformatics. 2009;25:1972-3.

46. Price MN, Dehal PS, Arkin AP. FastTree 2-approximately maximum-likelihood trees for large alignments. PLOS ONE. 2010;5:e9490.

47. Aris-Brosou S, Rodrigue N. The essentials of computational molecular evolution. Evolutionary genomics. In: Methods in molecular biology. pp 111-52. Humana Press, Totowa, NJ, USA; 2012.

48. Mai U, Mirarab S. TreeShrink: efficient detection of outlier tree leaves. In: Comparative genomics, Springer International Publishing, Cham, Switzerland; 2017.

49. Bates D, Mächler M, Bolker B, Walker S. Fitting linear mixedeffects models using lme4. J Stat Softw. 2015;67:2562-72.

50. Frossard A, Donhauser J, Mestrot A, Gygax S, Bååth E, Frey B. Long- and short-term effects of mercury pollution on the soil microbiome. Soil Biol Biochem. 2018;120:191-9.

51. Larose C, Prestat E, Cecillon S, Berger S, Malandain C, Lyon D, et al. Interactions between snow chemistry, mercury inputs and microbial population dynamics in an Arctic snowpack. PLOS ONE. 2013;8:e79972.

52. Paulson JN, Stine OC, Bravo HC, Pop M. Robust methods for differential abundance analysis in marker gene surveys. Nat Methods. 2013;10:1200-2.

53. McMurdie PJ, Holmes S. phyloseq: an R package for reproducible interactive analysis and graphics of microbiome census data. PLOS ONE. 2013;8:e61217.

54. Oksanen J, Blanchet FG, Friendly M, Kindt R, Legendre P, McGlinn D, et al. Vegan: community ecology package, 2.5-6. 2019. http://CRAN.R-project.org/package =veganhttp://CRAN.Rproject.org/package $=$ vegan.

55. Paradis E, Claude J, Strimmer K. APE: analyses of phylogenetics and evolution in R language. Bioinformatics. 2004;20:289-90.
56. Murtagh F, Legendre P. Ward's hierarchical agglomerative clustering method: which algorithms implement ward's criterion? J Classif. 2014;31:274-95.

57. Drummond AJ, Suchard MA, Xie D, Rambaut A. Bayesian phylogenetics with BEAUti and the BEAST 1.7. Mol Biol Evol. 2012;29:1969-73.

58. Parker J, Rambaut A, Pybus OG. Correlating viral phenotypes with phylogeny: accounting for phylogenetic uncertainty. Infect Genet Evol. 2008;8:239-46.

59. Wang TH, Donaldson YK, Brettle RP, Bell JE, Simmonds P. Identification of shared populations of human immunodeficiency virus type 1 infecting microglia and tissue macrophages outside the central nervous system. J Virol. 2001;75:11686-99.

60. Drummond AJ, Rambaut A, Shapiro B, Pybus OG. Bayesian coalescent inference of past population dynamics from molecular sequences. Mol Biol Evol. 2005;22:1185-92.

61. Wright MN, Ziegler A. Ranger: a fast implementation of random forests for high dimensional data in $\mathrm{C}++$ and R. J Stat Softw. 2015; https://doi.org/10.18637/jss.v077.i01.

62. Jones Z, Linder F. edarf: Exploratory data analysis using random forests. J Open Sour Softw. 2016;1:92-6. https://doi.org/10. 21105/joss.00092.

63. Muggeo VMR. segmented: An $\mathrm{R}$ package to Fit Regression Models with Broken-Line Relationships. R NEWS. 2008;8:20-5.

64. Drummond AJ, Ho SYW, Phillips MJ, Rambaut A. Relaxed phylogenetics and dating with confidence. PLoS Biol. 2006;4:e88.

65. Ruuskanen MO, St. Pierre KA, St. Louis VL, Aris-Brosou S, Poulain AJ. Physicochemical drivers of microbial community structure in sediments of Lake Hazen, Nunavut, Canada. Front Microbiol. 2018;9:1138.

66. Pérez-Rodríguez M, Silva-Sánchez N, Kylander ME, Bindler R, Mighall TM, Schofield JE, et al. Industrial-era lead and mercury contamination in southern Greenland implicates North American sources. Sci Total Environ. 2018;613-614:919-30.

67. Stearns PN. The Industrial Revolution in world history. 4th ed. Routeledge, New York, NY, USA; 2018.

68. Allan M, Le Roux G, Sonke JE, Piotrowska N, Streel M, Fagel N. Reconstructing historical atmospheric mercury deposition in Western Europe using: Misten peat bog cores, Belgium. Sci Total Environ. 2013;442:290-301.

69. Clackett SP, Porter TJ, Lehnherr I. 400-year record of atmospheric mercury from tree-rings in Northwestern Canada. Environ Sci Technol. 2018;52:9625-33.

70. Hughes MN, Poole RK. Metal speciation and microbial growththe hard (and soft) facts. Microbiology. 1991;137:725-34.

71. Chiasson-Gould SA, Blais JM, Poulain AJ. Dissolved organic matter kinetically controls mercury bioavailability to bacteria. Environ Sci Technol. 2014;48:3153-61.

72. Mangal V, Stenzler BR, Poulain AJ, Guéguen C. Aerobic and anaerobic bacterial mercury uptake is driven by algal organic matter composition and molecular weight. Environ Sci Technol. 2019;53:157-65.

73. Kassen R. Experimental evolution of innovation and novelty. Trends Ecol Evol. 2019;34:712-22.

74. United Nations Environment Programme (UNEP), Minamata Convention on Mercury In: Minamata Convention on Mercury. UN Treaty Collection, Minamata, Japan; 2013. http://treaties.un. org/doc/Treaties/2013/10/20131010\%2011-16\%20AM/CTCXXVII-17.pdf.

75. Wang F, Outridge PM, Feng X, Meng B, Heimbürger-Boavida LE, Mason RP. How closely do mercury trends in fish and other aquatic wildlife track those in the atmosphere? - Implications for evaluating the effectiveness of the Minamata Convention. Sci Total Environ. 2019;674:58-70.

76. Dirzo R, Young HS, Galetti M, Ceballos G, Isaac NJB, Collen B. Defaunation in the Anthropocene. Science. 2014;345:401-6. 
77. Parks DH, Rinke C, Chuvochina M, Chaumeil PA, Woodcroft BJ, Evans PN, et al. Recovery of nearly 8,000 metagenome-assembled genomes substantially expands the tree of life. Nat Microbiol. 2017;2:1533-42.

78. Finnish Environment Institute S. Vesistöennusteet: Kokemäenjoen vesistöalue. Finnish Environment Institute S: Harjavalta, 2011.

79. Gibson JJ, Reid R, Spence C. A six-year isotopic record of lake evaporation at a mine site in the Canadian subarctic: results and validation. Hydrological Processes. 1998;12:1779-92.

80. Reid R. Evaporation studies at mine tailings ponds in the Northwest Territories. In: Milburn, D (ed.) Proceedings of the HydroEcology Workshop on the Arctic Environmental Strategy-Action on Water, May 1996, Banff AB, NHRI Symposium No. 16. pp 115-33. National Hydrology Research Institute, Saskatoon, Alberta, Canada, 1997.

81. Bone A, Haldin L, Koivisto A-M, Mäenpää E, Mäensivu M, Pakkala J, Seppälä T (eds). Luodon-Öjanjärveen laskevien vesistöjen vesienhoidon toimenpideohjelma 2016-2021. EteläPohjanmaan ELY-keskus. Seinäjöki, Finland. Raportteja 45/2016. 2016. http://urn.fi/URN:ISBN:978-952-314-448-4.

82. Finnish Environment Institute SYKE. Päiväjärvi (84.048.1.002). Järviwiki. http://www.jarviwiki.fi/wiki/P\%C3\%A4iv\%C3\%A4j\% C3\%A4rvi_(84.048.1.002). 2011. Accessed: 15 Nov 2018.
83. Rühland KM, Hargan KE, Jeziorski A, Paterson AM, Keller W, Smol JP. A multi-trophic exploratory survey of recent environmental changes using lake sediments in the Hudson Bay Lowlands, Ontario, Canada. Arct, Antarct, Alp Res. 2014;46:139-58.

84. Ilmast NV, Sterligova OP. Biological characteristics of European whitefish in Lake Pulmankijarvi, northern Finland. Ergebnisse der Limnologie. 2002;57:359-66.

85. Mansikkaniemi $H$, Syrilä $S$. Main features of the glacial and postglacial development of Pulmanki valley in northernmost Finland. Instituti Geographici Universitatis Turkuensis, Turku, Finland; 1965. http://data.nationallibrary.fi/bib/me/W00399335800.

86. Petäjä A. Depth charts of some lakes in Utsjoki, Finnish Lapland. Ann Univ Turku A, II. 1964;32:346-9.

87. Kuusisto E. Suomen vesistöjen lämpötilat kaudella 1961-1975. Water Research Institute, Helsinki, Finland; 1981. https://core.ac. uk/download/pdf/14923103.pdf.

88. Emmerton CA, St. Louis VL, Lehnherr I, Graydon JA, Kirk JL, Rondeau KJ. The importance of freshwater systems to the net atmospheric exchange of carbon dioxide and methane with a rapidly changing high Arctic watershed. Biogeosciences. 2016;13:5849-63.

89. Pike G. Understanding temporal and spatial temperature variation at the local scale in a high latitude environment. PhD Thesis. University of Portsmouth, Portsmouth, UK; 2013. 